\title{
Study of Collaboration and Institutional Model on Kampung Kopi Development as a Part of Bandung 1000 Kampung Program
}

\author{
(Location of Study: Kampung Kopi Margamulya Village Pangalengan District, Bandung \\ Regency)
}

\author{
Sugeng Mulyono* \\ The Regional Secretariat of Bandung Regency \\ Bandung, Indonesia \\ *sugengmulyono157@yahoo.co.id
}

\author{
Endang Wirjatmi TL, Sait Abdullah \\ Polytechnic STIA LAN Bandung \\ Bandung, Indonesia \\ e.wirjatmi01@gmail.com \\ sait.abdullah@stialanbandung.ac.id
}

\begin{abstract}
Bandung 1000 Kampung program is a priority program which is set up on Bandung Regency regional mediumterm development plans. This program is focused on development issues such as education, health, tourism, investment and poverty. This program is using one village one product approach to encourage each region to develop their local potential. Since was established in 2018, Bandung 1000 Kampung had already involved various parties both government and nongovernment. One of the Bandung 1000 Kampung location that has been implemented by intervention activities is Kampung Kopi in Margamulya Village. The result of evaluation study showing that Bandung 1000 Kampung program yet implemented properly to help realized development program in Bandung regency including Kampung Kopi, several reason why it happened causes by lack of coordination, communication and public participation. This research is descriptive using a qualitative approach to identify implementation variables according to Edward (1980:148) including communication, resources, dispositions, and bureaucratic structures on Bandung 1000 Kampung program. This study aims to provide recommendations for the development of Kampung Kopi using collaborative form, therefore a review of previously research is needed regarding stakeholders as parties who will be involved in a collaboration.
\end{abstract}

Keywords-implementation, stakeholders, collaborative

\section{INTRODUCTION}

Bandung 1000 Kampung is a priority program in the Bandung Regency regional medium-term development plans year 2016-2021 which using one village one product (OVOP) approach to develop potential of each region and increases regional competitiveness. The program consists of five development themes to handle issues such as education, investment, poverty, tourism and health. The OVOP concept is used to split each region into several cluster consisting of
Agroforestry, Home Industry, Educational Services, Culinary, Panorama and Cultural Arts.

Implementation of Bandung 1000 Kampung program since established on 2018 had already involving several parties, including Government, Public and Academics. The result of evaluation of the program shows that the activities to support the program was not optimal due to lack of communication, coordination and Community involved. One of the program locations which have been received an intervention is Kampung Kopi as a part of Agroforestry Cluster in Margamulya Village, Pangalengan District.

The Agroforestry cluster is the only cluster established by Bandung Regent Regulation Number 50 of 2016 about Agroforestry Coffee Area in Pangalengan District, Bandung Regency. Development of Agroforestry Areas is directed at the potential of agriculture, farm, industries, tourism, and other potentials. However, current situation of Kampung Kopi development is still focused on cultivating coffee plants.

Based on the results of the evaluation about Bandung 1000 Kampung Program and current situation to develop Kampung Kopi as an Agroforestry Area, this research will focus on providing advice using collaborative approach. However, before giving some advice to the program this research identifies program implementation according to implementation success variables by Edward [1] consist of communication, resources, disposition, and bureaucratic structure. To support the requirement of analysis, this research will use the result of previous study about stakeholders mapping. The result of the analysis form previous studies will help researchers to formulate a recommendation for the development of Kampung Kopi as an Agroforestry Area as contained in the Bandung Regent Regulation Number 50 of 2016. 


\section{PROBLEM RESEARCH}

Problem research in this study are:

- How is the implementation of the program in Kampung Kopi viewed from implementation success variable according to Edward?

- How is the stakeholder role in development of Kampung Kopi?

- What kind of the right collaboration models for stakeholders in developing Kampung Kopi?

\section{RESEARCH PURPOSES}

Purposes of this research are:

- Identifying the fulfillment of the implementation success variable in Kampung Kopi program;

- Identifying stakeholder role in Bandung 1000 Kampung Program on Kampung Kopi; and

- Recommend the development of Kampung Kopi according to the direction, policies and strategies of the Agroforestry Area using stakeholder collaboration approach.

\section{METHODOLOGY RESEARCH}

This research is a descriptive study using a qualitative approach that focuses on solving problems about institutional issues that affect the success of Bandung 1000 Kampung Program in Kampung Kopi.

The analysis in this study is supported by the results of previous studies about the level of influence and interests of stakeholders to formulate recommendations for the development of Bandung 1000 Kampung program in Kampung Kopi.

\section{A. Research Sites}

Location of the study is Kampung Kopi at Margamulya Village, Pangalengan District, Bandung Regency. One of the considerations in locus selection is the support for legality aspect that contained in Bandung Regent Regulation 50/2016 as the basis for determining agroforestry areas.

\section{B. Data Collectoin Technique}

The data which use in this study are primary data and secondary data, while the collection technique is carried out by:

1) Primary Data. Obtained throughinterviews and observations. Interviews were conducted by involving informants who were selected on several aspect consist of enculturation aspect, involvement, time, objectivity and alienation to the program [2].
2) Secondary Data. Obtained through review of the study which is related and collecting documents from government institutional government that will be using for the analysis.

\section{THEORETICAL BASIS}

\section{A. Development Administration}

In the development administration, government plays a role as a driving force of the development to formulate an effective strategy. In order to achieve it, government collaboration models involving other parties as part of development is necessary [3]

\section{B. Policy and Program Implementation}

George Edward III [1] argue that there are four variables which is affect the level of success of the policies or program implementation, consist:

- Communication, determines the success of achieving the goals of implementation;

- Resources, an important implementation factor include staff, information, authority, facilities and financial support;

- Disposition, implementing support for policies/programs includes honesty, commitment and democracy; and

- Bureaucratic structure, including standard operational procedures (SOP), which functions to facilitate in implementing programs. And then fragmentation, which is the split roles and responsibilities of various parties that need coordination.

\section{Stakeholders}

Freeman [4] argue that stakeholders are a group/individual who can influence or being influenced by certain policies. Groenendijk [5] classified stakeholders into two categories according to level of influence and interests

- Interest in an attribute for stakeholders to see the objectivity of the policies that are assessed based on expectations, benefits, resources, interests, and participation.

- Influence, is the strength that stakeholders have on the program and can be assessed based on police support, influence ability, resources and expertise.

\section{Penta Helix Collaboration Model}

Penta helix is a form of collaboration involving five element parties consisting business, government, Community, academics and media [6]. Struesson [7] refer penta helix models as the improvement of the triple helix which is a form of cooperation by involving Community, non-profit organization and the business with the aim of innovating. 


\section{E. Partnership and Organization}

Organizational structure is the relationship between part of the organization in carry out an operation to achieve a goal [8]. Organizational structure divided a task of one party and another, Crosby [9] argues that organizations need to have this following capacity.

- Ability to connect an interest;

- Capacity to build support;

- Adapt to the new task;

- Lobbying and advocacy;

- Abilities to monitor and control implementations;

- Has a coordination mechanism; and

- Has a mechanism to monitor impact.

F. Logical Framework

\section{DISCUSSION}

\section{A. Kampung Kopi Implementation Program}

The implementation of program and activities that intervened by Regional Government need to identify regarding the suitability of implementation success variables that can determine level of program success [1].

\section{1) Communication}

The implementation of program and activities in Kampung Kopi have been socialized by the Government to the Community with Margamulya Village Government.

The Community has already understood that Kampung Kopi development program is accordance with the local potency in the agroforestry sector, but the interventions given by Government to support the program yet fulfill Community needs. Community needs as intended is housing improvements program (Rutilahu) which has not reached all levels of society.

Logical framework of this research can be seen in Figure 1.

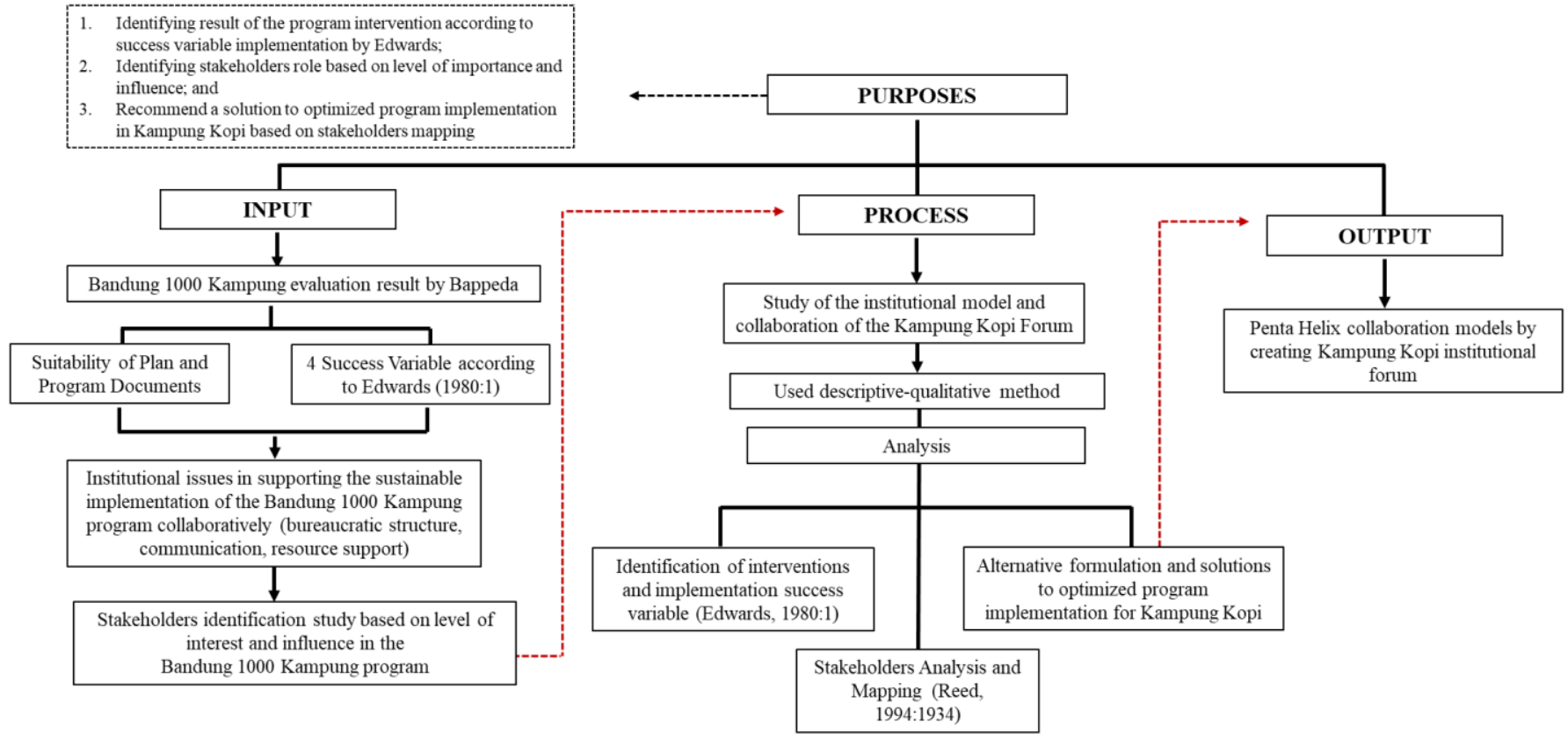

INFORMATION

------ : Purposes

Analysis linkages

Fig. 1. Logical Framework.

Communication as a variable that can affect level of success need to be clear, stakeholders in Kampung Kopi especially the Regional Government need to explain to the Community about limitedness on implementing the program. The limitations referred to implementation time and budget of program which the focus of development program in Kampung Kopi is not only about Rutilahu program. In addition, the proposed top-down activity intervention plan needs to be fixed using a bottom-up form in order to accommodate the aspirations of the Community. To solve this problem there is 
need a good public communication to facilitate Community interest in Kampung Kopi.

2) Resources. Human resources in Kampung Kopi have helped to realize the development policies as contained in Bandung Regent Regulation 50/2016. This is indicated by the livelihoods of people which engaged in the agricultural sector, livestock, trade services. Facilities and infrastructure which used in the development of Kampung Kopi consists of plant seeds, coffee pressing machines, sport infrastructure, roads, drainage, gates and so on

Meanwhile the support of authority consists the duties and functions of Bandung Regent and Chief of Village Government to urge staff and Community to be involved in the development of Kampung Kopi.

3) Dispositions. In Bandung Regent Regulations 50/2016, Kampung Kopi development is directed toward into the sociological, psychological, economic and community needs. Community in Kampung Kopi is fully committed to the program based on the value and benefits derived from the program. Apart from community, government and business are fully committed to support the program. however, the community believes that there is a need for improvement in the governance of program implementation, especially regarding to community aspirations.

4) Bureaucratic Structure. Bandung 1000 Kampung program which involves cross-sector cooperation currently doesnot have an institution as part of the bureaucratic structure. Limitations of duties and function from several parties affected program which running ineffective.

Description of the stakeholders showed that implementation of the program not only involved Government Agencies, so there is necessary to create a forum as a tool for communication and exchange of information for cross-sectors including non-government agencies.

Based on the identification regarding the fulfillment of program success variables [1] in the intervention activities in Kampung Kopi, show that the government need to the implementation of program. The existence of nongovernmental elements with an interest in programs such as the community and business show the need for synergy between parties in realizing development in Kampung Kopi. Synergy is needed for the sustainability of the intervention in Kampung Kopi, which the development is directed at the agriculture, livestock, industry and tourism sectors. Tourism can be another excellent potential besides the cultivation of coffee plants, including the existence of the Cultural Village assisted by DPMD Bandung Regency, and panoramas such as in Cibercek Village which has the potential to attract tourists.

\section{B. Stakeholders Analysis}

Stakeholder analysis based on the results of previous research identifies the role of stakeholders based on their level of importance and influence. The stakeholders whose involved in the Bandung 1000 Kampung Program in Kampung Kopi can be seen in Table 1.

TABLE I. IDENTIFYING OF STAKEHODLERS

\begin{tabular}{|l|l|l|l|}
\hline No. & \multicolumn{1}{|c|}{ Stakeholders } & \multicolumn{1}{|c|}{ Classificaton } & \multicolumn{1}{|c|}{ Information } \\
\hline 1 & Sekretariat Daerah & Government & Already involved \\
\hline 2 & Bappeda & Government & Already involved \\
\hline 3 & $\begin{array}{l}\text { Dinas Koperasi dan } \\
\text { UKM }\end{array}$ & Government & Already involved \\
\hline 4 & $\begin{array}{l}\text { Dinas Perdagangan } \\
\text { dan Perindustrian }\end{array}$ & Government & Already involved \\
\hline 5 & Dinas PU dan TR & Government & Already involved \\
\hline 6 & $\begin{array}{l}\text { Dinas Lingkungan } \\
\text { Hidup }\end{array}$ & Government & Already involved \\
\hline 7 & Dinas Perkimtan & Government & Already involved \\
\hline 8 & $\begin{array}{l}\text { Dinas Komunikasi } \\
\text { dan Informasi }\end{array}$ & Government & Already involved \\
\hline 9 & Dinas PMD & Government & Already involved \\
\hline 10 & Dinas Tenaga Kerja & Government & Already involved \\
\hline 11 & Dinas Pertanian & Government & Already involved \\
\hline 12 & $\begin{array}{l}\text { Dinas Pariwisata } \\
\text { dan Kebudayaan }\end{array}$ & Government & Already involved \\
\hline 13 & Dinas Perhubungan & Government & Already involved \\
\hline 14 & Masyarakat, & Community & Already involved \\
\hline 15 & $\begin{array}{l}\text { Civitas Akademisi } \\
\text { Perguruan Tinggi }\end{array}$ & Academic & Already involved \\
\hline 16 & Pelaku Usaha & Business & Already involved \\
\hline 17 & $\begin{array}{l}\text { Media } \text { Elektronik } \\
\text { Sosial) }\end{array}$ & Media & $\begin{array}{l}\text { Need } \\
\text { involved }\end{array}$ \\
\hline
\end{tabular}

Source: Result of Previous Research about Stakeholders Analysis in Bandung 1000 Kampung Program, 2020

1) Stakeholders Classification. Stakeholders in Table 2 based on the level of influence and interest on the program are divided into four categories [10]:

a) Key Players. Stakeholders in this category are parties with a high level of interest and influence on the program. Regional Government of Bandung Regency as development administrator is classified as key players according to their capacity and authority. In addition, academics are also classified in this category because of their ability to help Regional Government on formulate ideas and innovation in developing Kampung Kopi as an Agroforestry Area.

b) Subject. Stakeholders in this category are parties with a high level of interest but not have a ability to influence the implementation of program. Stakeholders who classified in this category are Perum Perhutani and Coffee Producer. Coffee producers have a high interest in reaping profits but did not have an ability to influence the program due to lack of authority.

c) Context Setters. Stakeholders in this category consist of parties with a low interest but have a high influence on the implementation of program. Stakeholders who classified in this category are Department of Transportation in Bandung Regency Regional Government and Media. The Media is the party that has the ability to influence and create public opinion 
regarding Bandung 1000 Kampung program in Kampung Kopi.

d) Crowd. Crowd is a stakeholder with low interest and influence on the program. These stakeholders have the potential to give a contribution to the program implementation. The result of the stakeholders mapping show that community is classified in this category which included residents, farmer groups and Lembaga Masyarakat Desa Hutan (see figure 2).

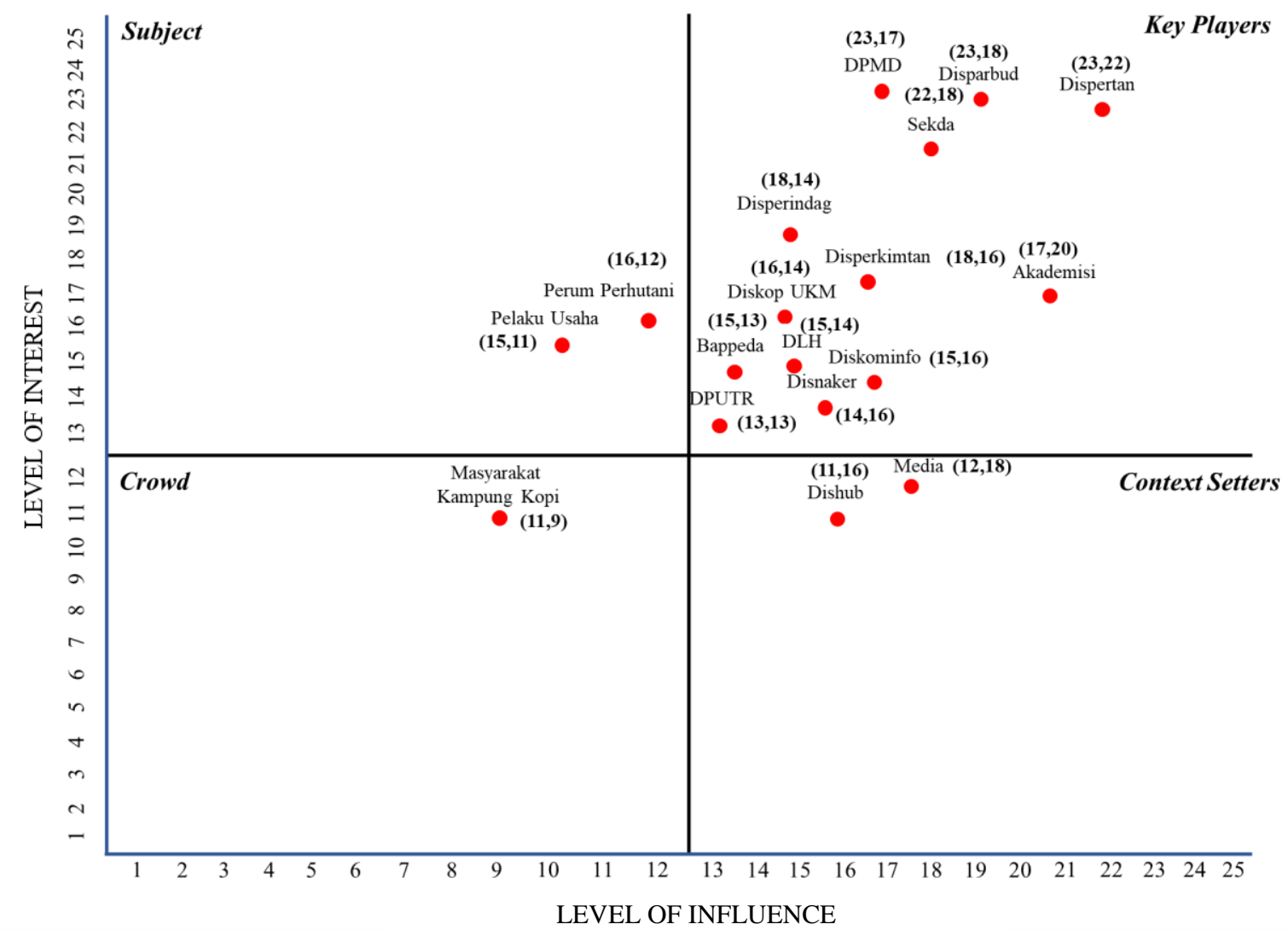

Source: Result of Previous Research about Stakeholders Analysis in Bandung 1000 Kampung Program, 2020

Fig. 2. Stakeholders Mapping of Kampung Kopi on 1000 Kampung Program.

The identification of stakeholders involved on Kampung Kopi program shows a tendency for penta-helix collaboration model. To support cross-stakeholder collaboration, it is necessary to create an institution to fulfill the fragmentation aspect in the form of division of duties and responsibility from each party according to their capacity and authority. Penta helix collaboration needs to be supported by the ability to facilitate the interest of stakeholders with good coordination and advocacy mechanism.

\section{Development of Kampung Kopi}

Based on the result of program evaluation which refers to the fulfillment of the variable elements of successful implementation according to Edward [1] shows the reasons why program implementation was unsuccessful can be influenced by lack of communication aspect and support of bureaucratic structures. To support the implementation of program, collaboration is required by creating institutional form as a forum for facilitate communication and coordination.

The proposed of institutional form taking into current condition in development of Kampung Kopi is with create a forum. Kampung Kopi Forum was formed to facilitate the interest of the Regional Government as development administrator in Bandung Regency and the interest of community and the business and as parties who have affected by Bandung 1000 Kampung Program in Kampung Kopi. Collaboration in the form of a forum needs to fulfill its function of advocacy, coordination, communication and monitoring function towards the achievement of common goals which set up in both Regional Development Midterm Plan and Bandung Regent Regulation on Agroforestry Areas (see figure 3). 


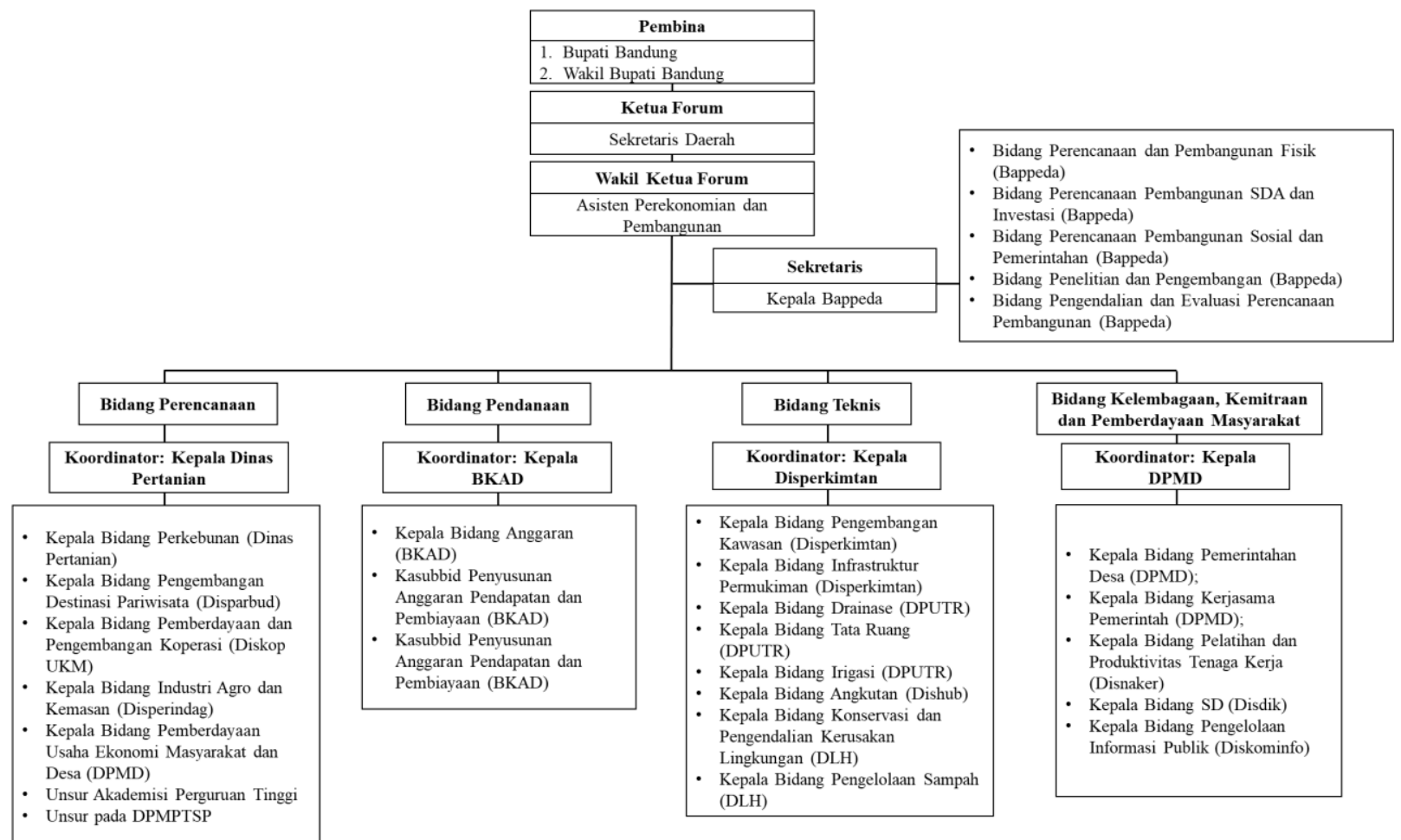

Source: Result of Previous Research about Stakeholders Analysis in Bandung 1000 Kampung Program, 2020

Fig. 3. Organizational Structure of Kampung Kopi Forum on Bandung 1000 Kampung Program.

The institutional structure in the Kampung Kopi Forum on Bandung 1000 Kampung Program consist of elements of the founder, chairman, vice chairman, secretariat and four sectors that are formed according to development needs. Details of the organizational structure in Kampung Kopi Forum can be seen as follows.

- Founder, led by elements of Bandung Regent and Vice of Bandung Regent who have the authority to give instruction for implementing planned activities in Kampung Kopi

- Chairman of the Forum, led by the Regional Secretary, whose broad duties and functions are to direct forum members to carry out their duties according to capacity, functions and authorities.

- Vice Chairman of the Forum, led by Assistant for Economy and Development who assists in the duties and function of the forum chairman.

- The Secretariate, led by the head of Bappeda Bandung Regency who helps formulate policies and strategic on developing Kampung Kopi.

- Development Sectors, consisting of the Planning Sector, Funding Sector, Technical Field Sector, Partnership and Community Empowerment Sector. Each sector is led by a coordinator who has background as regional government agency and support by academia, society, business and media. Coordinator from each sector in carrying out duties and functions according to their capacity supported by the role of members.

\section{CONCLUSIONS AND RECOMMENDATIONS}

\section{A. Conclusions}

The results of this research are summarized as follows:

- Kampung Kopi Forum was formed as an effort to fulfill the success of program implementation and as a forum for stakeholders with the functions of communication, coordination and advocacy;

- To optimize the development of Kampung Kopi, it is necessary to pay attention to other potentials as an attraction for the Agroforestry Area in accordance with Bandung Regent Regulation Number 50 of 2016;

- Kampung Kopi Forum concsists of stakeholders based on their level of importance and influence, having their responsibilities and duty including key players, subject, context setters and the crowd; 
- Kampung Kopi Forum was formed by considering the basics of organization and partnerships to be responsible for meeting the development targets set in accordance with the planned documents of Bandung Regency Regional Development Midterm Plan of 20162021 and Bandung Regent Regulation of Agroforestry Areas.

\section{B. Recommendations}

The recommendations proposed from the results of this study are:

- With the created of Kampung Kopi Forum, expected that stakeholders can collaborate in formulating policies and programs in accordance with the development indicators which set up in Bandung Regency Regional Development Midterm Plan of 2016-2021 and Bandung Regent Regulation of Agroforestry Areas;

- Formulation of policies and formulation of programs by Forum members need to be adjusted to the development targets in phase IV of Bandung Regency Regional Development Long-term Plan of 2005-2025, it is expected that the implementation can be sustainable;

- Kampung Kopi institutional forming by a Forum needs to be followed up and appointed with a Bandung Regent Decree or Bandung Regent Regulation.

\section{REFERENCES}

[1] G.C. Edwards, "Implementing Public Policy". Washington DC: Congressional Quarterly Inch. 1980.

[2] S. Sugiyono, "Metode Penelitian Kebijakan”. Bandung: Alfabeta. 2017.

[3] S. Anggara \& I. Sumantri, "Adminsitrasi Pembangunan Teori dan Praktik (1 ed.)”. Bandung: CV. Pustaka Setia. 2016.

[4] R.E. Freeman, "Strategic Management: A Stakeholders Approach". Boston: Fitman. 1984.

[5] E.M.C. Groenendijk \& E.J.M. Dopheide, "Planning and management tools". Enschede: ITC. 2003.

[6] H.A. Muhyi, A. Chan, I. Sukoco, and T. Herawaty, The Penta Helix collaboration model in developing centers of flagship industry in Bandung city. "Review of Integrative Business and Economics Research", 6(1), pp.412-417. 2017.

[7] E. Sturesson, Lindmark, Adam, R. Nilson, \& Markus, "Collaboration for Innovation - A Study in the Oresund Region", Sweden. Lund: Lund University Libraries. 2009.

[8] L.A. Modeong, "Proses Formulasi Kebijakan Pembentukan Kelembagaan Pemerintah Daerah Istimewa Yogyakarta Berdasarkan Undang-undang Keistimewaan pada Tahun 2015”. Yogyakarta: Universitas Muhammadiyah Yogyakarta. 2015.

[9] P.B. Crosby, "The Absolutes of Leadership". San Diego: Pfeiffer \& Company. 1996.

[10] M.S. Reed, A. Graves, N. Dandy, H. Posthumus, K. Hubacek, Morris, L.C. Stringer, Who's in and why? A typology of stakeholder analysis methods for natural resource management. "Journal of Environment Management", 90, 1933-1949. 2009. 